\title{
Prostatic calculi cause osteoblastic immunophenotype of prostate cancer
}

\author{
A.M. Piddubnyi ${ }^{1, A-F}$, S. M. Danylchenko $0^{2, B, B, F}$, A. M. Romaniuk ${ }^{1, C, E, F}$, R. A. Moskalenko ${ }^{\star 1, A-F}$ \\ ${ }^{1}$ Sumy State University, Ukraine, ${ }^{2}$ Institute of Applied Physics, National Academy of Sciences of Ukraine, Sumy
}

A - research concept and design; B - collection and/or assembly of data; C - data analysis and interpretation; D - writing the article;

$\mathrm{E}$ - critical revision of the article; $\mathrm{F}$ - final approval of the article

Key words: prostate cancer, prostatic calculi, bone neoplasms, osteotropism, osteoblastic immunophenotype.

Pathologia 2019; 16 (2), 170-176 DOI: 10.14739/2310-1237 2019.2.177099

*E-mail: r.moskalenko@med. sumdu.edu.ua
Prostate cancer (PGC) is leading the way in the structure of cancer morbidity around the world. The presence of prostatic concretions $(\mathrm{PC})$ and skeletal metastases significantly reduces the patients' life quality and worsens the prognosis of the disease. Aim. The aim of study was to define the impact of PC on the development of prostate cancer bone metastases.

Materials and methods. 30 samples of PGC with PC and 30 PGC tissue samples without PC were analyzed by histology (hematoxylin-eosin staining), histochemistry (von Kossa and Alizarin red staining), immunohistochemistry (OSN, Col I, Col II, p53, Bax, Casp3, MPO, CD68). PC were analyzed by SEM-EDS and XRD with different temperature of heat pretreatment.

Results. All PC samples had the calcium hydroxyapatite origin with a slight deviation from the stoichiometric composition and admixture of extraneous elements. The presence of zinc oxide and iron-containing calcium phosphate in the structure of PC was found by XRD. We revealed significantly higher expression of Bax, Casp3, MPO and CD68 in PGC tissue with PC $(P<0.001)$. We suggest that the combination of these factors predetermines the development of a specific phenotype of cancer cells which is manifested by the significantly higher OSN and Col I expression in PGC with $P C(P<0.001)$. It contributes to recognizing of bone tissue as an optimal environment for the growth and development of PGC metastases by cancer cells.

Conclusions. The presence of $P C$ in the PGC tissue promotes the development of a specific osteoblastic immunophenotype of cancer cells. It can determine the tropism of PGC metastases to bone tissue.
Ключові слова: рак передміхурової залози, простатичні конкременти, кісткові метастази, остеотропізм, остеобластичний імунофенотип.

Патологія. - 2019. T. 16, № 2(46). C. 170-176

\section{Простатичні конкременти зумовлюють остеобластичний імунофенотип раку передміхурової залози}

\section{А. М. Піддубний, С. М. Аанильченко, А. М. Романюк, Р. А. Москаленко}

Рак передміхурової залози (РПЗ) посідає провідні позиції у структурі онкологічної захворюваності та смертності чоловіків у всьому світі. Наявність простатичних конкрементів (ПК) і метастатичного ураження скелета значно знижує якість життя пацієнтів і погіршує перебіг основного захворювання.

Мета роботи - визначення можливого впливу наявності ПК на процеси розвитку кісткових метастазів РПЗ.

Матеріали та методи. 30 зразків тканини РПЗ із ПК і 30 зразків неопластичної тканини РПЗ без ознак біомінералізації дослідили за допомогою гістологічних (забарвлення гематоксиліном та еозином), гістохімічних (забарвлення алізариновим червоним і за методом фон Косса) та імуногістохімічних (з використанням антитіл проти маркерів OSN, Col I, Col II, p53, Bax, Casp3, MPO, CD68) методів. Усі ПК аналізували за допомогою SEM-EDS i XRD з різними температурними режимами обробки матеріалу.

Результати. Усі зразки досліджених ПК складалися переважно із кальцію гідроксиапатиту з незначними відхиленнями у стехіометричному складі та домішками сторонніх елементів. За допомогою XRD з обробкою матеріалу при $900^{\circ} \mathrm{C}$ встановили наявність оксиду цинку та залізовмісного кальцію фосфрату в хімічному складі ПК. Визначили значно вищі рівні експресії Bax, Casp3, MPO та CD68 у пухлинній тканині РПЗ із наявністю ПК $(p<0,001)$. Вважаємо, що комбінація цих фракторів створює умови для розвитку специфічного фенотипу пухлинних клітин, що проявляється підвищеною експресією OSN та Col I неопластичною тканиною РПЗ із ПК $(p<0,001)$. Це спричиняє розпізнавання кісткової тканини пухлинними клітинами як оптимального мікрооточення для розвитку та росту метастазів РПЗ.

Висновки. Наявність ПК у тканині РПЗ супроводжується розвитком специфічного остеобластичного імунофенотипу пухлинних клітин. Це може зумовлювати тропізм РПЗ до розвитку кісткових метастазів.
Ключевые слова: рак преАстательной железы, костные метастазы, остеотропизм, остеобластический иммунофенотип.

Патология. - 2019. T. 16, № 2(46). C. 170-176

\section{Простатические конкременты обуславливают остеобластический иммунофенотип рака предстательной железы}

\section{А. М. Подаубный, С. Н. Аанильченко, А. Н. Романюк, Р. А. Москаленко}

Рак предстательной железы (РПЖ) занимает ведущие позиции в структуре онкологической заболеваемости и смертности мужчин по всему миру. Наличие простатических конкрементов (ПК) и метастатических поражений скелета значительно снижает качество жизни пациентов и ухудшает течение основного заболевания.

Цель работы - определение возможного влияния наличия ПК на процессы развития костных метастазов РПж.

Материалы и методы. 30 образцов ткани РПЖ с ПК и 30 образцов неопластической ткани РПж без признаков биоминерализации исследовали с помощью гистологических (окраска гематоксилином и эозином), гистохимических 
(окраска ализариновым красным и по методу фон Косса) и иммуногистохимических (с использованием антител против маркеров OSN, Col I, Col II, p53, Bax, Casp3, MPO, CD68) методов. Все ПК проанализировали с помощью SEM-EDS и XRD с разными температурными режимами обработки материала.

Результаты. Все исследованные ПК состояли преимущественно с кальция гидроксиапатита с незначительными отклонениями в стехиометрическом составе и примесями посторонних элементов. С помощь XRD с обработкой материала при $900{ }^{\circ} \mathrm{C}$ установлено наличие оксида цинка и железосодержащего кальция фосфрата в химическом составе ПК. Отмечены значительно более высокие уровни экспрессии Bax, Casp3, MPO и CD68 в опухолевой ткани PПЖ с наличием ПК ( $p<0,001)$. Считаем, что комбинация указанных факторов создает условия для развития специфического фенотипа опухолевых клеток, что проявляется повышенной экспрессией OSN и Col I в неопластической ткани РПЖ ( $<<0,001)$. Это способствует распознаванию костной ткани опухолевыми клетками в качестве оптимального микроокружения для развития и роста метастазов РПЖ.

Выводы. Наличие ПК в ткани РПЖ сопровождается развитием специфического остеобластического иммунофенотипа опухолевых клеток. Это может обуславливать тропизм РПЖ к развитию костных метастазов.

Prostate cancer (PGC) is the most common malignancy with high frequency of bone metastasis [1-3]. $70 \%$ of PGC cases are complicated by the development of bone metastases [4]. There is a close relationship between inflammation and carcinogenesis in the prostate. The most common causes of inflammation, epithelial injury and disturbance of secretion are intraluminal inclusions, particularly prostatic calculi (PC), and corpora amylacea [5]. Thus, the presence of $\mathrm{PC}$ in the peripheral zone of the prostate positively correlates with PGC progression [6]. Nevertheless, the mechanisms of bone metastases development in PGC patients, as well as the formation of PC, are unknown [7]. PGC cells are able to synthesize substances with a significant osteostimulatory effect, in particular, prostate specific antigen, endothelin-1, insulin-like growth factor 1 and others. These compounds have a direct effect on the osteogenesis in metastasis foci of PGC and possibly PC development in PGC tissue [8]. Similar substances, other than prostate specific antigen, also have been found in bone tissue $[9,10]$. Thus, the phenomenon of osteomimicry (the development of the "osteoblastic phenotype" of tumor cells as an adaptive mechanism) occurs [11].

However, there are no studies on the evaluation of the possibility of osteoblastic phenotype development in the cells of primary tumor before the metastasis processes, which could indicate the osteotropism of PGC metastases. The possible impact of the PGC immunophenotype on the bone metastasis development is in the focus of this article.

\section{Aim}

The aim of study was to define the impact of PC on the development of prostate cancer bone metastases.

\section{Materials and methods}

The Ethics Committee. The research was approved by the Ethics Committee of Medical Institute of Sumy State University (protocol 1/1, April 8, 2019).

Samples of tumor tissue. 30 samples of PGC with the presence of $P C$ and 30 samples of PGC without them were used for the study. All samples of PGC tissue were presented by surgical material after radical prostatectomy. Surgeries were performed at Sumy Regional Clinical Hospital and Sumy City Hospital №1 (Sumy, Ukraine). Informed consent was obtained from all the patients.

Histological examination. All material was fixed in a neutral (buffered) $10 \%$ solution of formaldehyde for at least
24 hours. After dehydration and saturation with paraffin, histological blocks were formed. Serial sections with a thickness of $4 \mu \mathrm{m}$ were made on a Shandon Finesse 325 rotary microtome (Thermo Scientific). After deparaffinization and dehydration (xylene and ethanol), the histological sections were stained with hematoxylin and eosin. All tumor samples were analyzed according to the Gleason score.

Histochemical study of samples. To determine the presence of calcium salts, sections were stained with a $2 \%$ Alizarin red solution at pH 4.2 for 5 minutes (by McGheeRussel) under visual control. After that specimens were submerged to the absolute acetone for 10-20 seconds.

The von Kossa staining was used to verify the presence of calcium phosphate in the structure of PC. The rehydrated histological sections were treated with $5 \%$ aqueous solution of silver nitrate under the direct light of 60 W lamp for 60 minutes. Subsequently, the tissue samples were treated with sodium thiosulfate $(5 \%$ aqueous solution). Nuclei were counterstained with aqueous solution of nuclear fast red (1:1000).

Detection of concretions. Large-sized concretions (macroscopic PC with a diameter more than $0.1 \mathrm{~cm}$ ) were detected during the collection of samples of PGC tissue or during the processing of histological samples. Small-sized PC (microscopic PC with a diameter less than $0.1 \mathrm{~cm}$ ) were detected in native preparations with a fluorescence microscope Zeiss Axio Lab A1 (excitation wavelength $495 \mathrm{~nm}$ ) or in histological specimens stained with hematoxylin and eosin.

Immunohistochemistry of PGC tissue. Serial sections with a thickness of $4 \mu \mathrm{m}$ were made from prepared histological paraffin blocks and applied to the SuperFrost adhesive slides (Thermo Scientific). The deparaffined sections were subjected to the antigen unmasking by the heat treatment in $0.1 \mathrm{M}$ citrate buffer $(\mathrm{pH} \mathrm{6.0)}$ ) at of 95-98 ${ }^{\circ} \mathrm{C}$. The "UltraVision Quanto Detection System HRP Polymer" (Thermo Scientific, USA) was used to visualize the immunohistochemistry $(\mathrm{IHC})$. Endogenous peroxidase activity was blocked by $3 \%$ hydrogen peroxide. "Ultra $\checkmark$ Block" was used to prevent non-specific reaction and background staining. Reaction was amplified with "Primary Antibody Amplifier Quanto". Diaminobenzidine (DAB) was used as a chromogen. The nuclei were counterstained with Mayer's hematoxylin. Primary antibodies ("Thermo Scientific", USA) against SPARC osteonectin (OSN) (Thermo Fisher Scientific, clone 5031, dilution 1:500), Collagen I (Col I) (Thermo Fisher Scientific, polyclone, dilution 1:200), Collagen II (Col II) (Thermo Fisher Scientific, clone 2b1.5, 
dilution 1:200), proapoptotic proteins p53 (Thermo Fisher Scientific, clone SP5, dilution 1:100), Bax (Santa Cruz Biotechnology, polyclone, dilution 1:100) and Activated Caspase 3 (Casp3) (Abcam, polyclone, ab13847, dilution 1:200), myeloperoxidase (MPO) (Thermo Fisher Scientific, polyclone, dilution 1:200) and CD68 (Thermo Fisher Scientific, clone SK1, dilution 1:200) were used.

The morphometric evaluations were carried out by the "Panoramic Viewer" (3DHistech, Hungary) and "Zen 2.0" (Carl Zeiss, Germany) software. Immunopositive cells were counted in a round-shaped fields of view with a diameter of $1000 \mu \mathrm{m}$. At least 6 fields of every specimen were analyzed. Col I and Col II expression was evaluated by the proportion of positive tissue in field of view with diameter $1000 \mu \mathrm{m}$ in ImageJ.

All photos were made by digital imaging systems "Zen 2.0" for "Carl Zeiss" microscopes (Germany) and "Panoramic Scanner" (3DHistech, Hungary). We used active (tissue with predetermined positive and negative reactions) and passive (internal) controls of $\mathrm{IHC}$.

Determination of the mineral component. PC were immersed in an organic epoxy resins blend. Samples were hardened at room temperature for 3 days. After that, the slabs of PC were made. Their surface was treated by carbon spraying. The specimen analysis was performed on a REMMA $100 \mathrm{U}$ scanning electron microscope with energy-dispersive X-ray spectrometer (Selmi, Ukraine). The X-ray diffraction (XRD) was performed on a diffractometer "DRON4-07" (Burevisnik, Russia) with CuKa radiation $(\lambda=0.154 \mathrm{~nm})$ under Bragg-Brentano focusing $(\theta-2 \theta)(2 \theta-$ Breggian angle). The samples were continuously recorded (speed $2 \theta / \mathrm{min}$ ) in the range of angles of $2^{\circ}$ from $10^{\circ}$ to $70^{\circ}$. Heat treatment of the samples was carried out at two different temperature modes: $200{ }^{\circ} \mathrm{C}$ and $900^{\circ} \mathrm{C}$. DIFWIN-1 (LLC "Etalon WTC") software was used for a preliminary processing of experimental results and Crystallographica Search-Match (Oxford Cryosystems) package for identification of the crystalline structure and phase composition.

Statistical analysis, The normality of data distribution was checked by Shapiro-Wilk test. Student's t-test was applied for analysis of data with a normal distribution. Mann-Whitney's U-test was applied for nonparametric data-sets. The results were considered statistically significant with a probability of more than $95 \%(P<0.05)$. Statistical analysis was performed in Microsoft Office Excel 2016 with addon AtteStat (version 12.0.5).

\section{Results}

Macroscopic study. Prostate gland with PGC and numerous PC contained from one to several PC which were localized predominantly in the peripheral areas of the organ. Prostate glands (after fixation in $10 \%$ formaldehyde solution) had a gray-brown color, they were enlarged (from $2.5 \mathrm{~cm}$ to $7.5 \mathrm{~cm}$ in diameter), they had a tubercular surface and a dense, solid consistency. The cut revealed multiple small cysts $(0.1-1.0 \mathrm{~cm}$ in diameter) and the nodular structure of the organ. Some of the cysts were filled with solid concretions from $0.1 \mathrm{~cm}$ to $0.8 \mathrm{~cm}$ in diameter (mean $0.37 \pm 0.06 \mathrm{~cm}$ ) (Fig. 1a). These formations were predominantly rounded, their color varied from dark brown to light yellow. Small concretions (less than $0.3 \mathrm{~cm}$ in diameter) had a polygonal shape (Fig. 1b). Hemorrhages and tissue hardening were revealed in PGC tissue around the PC. In some cases, single PC with a larger diameter (more than $0.3 \mathrm{~cm}$ ) had been found. These PC were characterized by a lighter color (Fig. 1b). PGC was detected as a dense grayish node without clear borders.

Detection of microscopic PC. During the microscopic examination of native specimens with a phase contrast, $\mathrm{PC}$ were visualized as translucent rounded formations (Fig. 1c). In fluorescence with $495 \mathrm{~nm}$ excitation wave PC had an intensive signal that exceeded the background of the connective tissue (Fig. 1d).

Histological examination. All samples were represented by acinar adenocarcinoma of the prostate with a Gleason score from 6 to 10. High-grade tumors were represented by solid tumor fields, strands or layers of neoplastic cells (Fig. 1e). The PC had a homogeneous structure and size up to $1000 \mu \mathrm{m}$. These inclusions were located in the lumen of glands or directly in the tumor tissue. The mean diameter of microscopic PC was $258.98 \pm 41.50 \mu \mathrm{m}$.

All samples of PGC had a variable inflammatory infiltration. In PGC samples with PC a significant number of hemorrhages, necrosis and a cystic tissue transformation were observed.

The majority of PC had a damaged structure or have been fragmented during sample processing.

Histochemical study. Alizarin red staining revealed bright red areas which matched to the localization of PC or their fragments (Fig. 1f). Von Kossa staining identified the presence of calcium phosphate in PC due to black colorization of PC fragments (Fig. 1g).

Immunohistochemistry. The samples were examined for the expression of osteoblastic markers: Col I and OSN. Anti-Col II antibodies were used as a negative control.

Col I expression was detected in the tumor's stroma between the tumor glands as some colored fibers (Fig. 1h). In PGC with PC $36.22 \pm 1.53 \%$ of neoplastic tissue area was positive for Col I expression. For PGC samples without $P C$ this value was $28.19 \pm 1.17 \%(P<0.001)$.

The IHC of PGC with anti-Col II antibodies indicated its slight expression as single colored fibers of connective tissue and sediments in the stroma (Fig. 1i). In PGC with PC, the expression of this marker was identified in $9.60 \pm 0.75 \%$ of the area of the sample. Col II was expressed in $10.50 \pm 0.86 \%$ of tumor area $(P>0.05)$ in the tissue of PGC without PC.

OSN had a distinct cytoplasmic expression pattern in tumor cells and inflammatory infiltrate cells. This glycoprotein was also identified in the structure of PC, where it had a diffuse coloration pattern (Fig. 1j). Samples of PGC with PC had $77.57 \pm 5.65$ OSN-positive neoplastic cells. This value was $36.8 \pm 2.5(P<0.001)$ for PGC tissue without PC.

Assessment of apoptotic potential of PGC was carried out by IHC-detection of p53, Bax and Casp3 proteins. p53 protein had a nuclear pattern of expression. Localization of p53-positive cells predominantly corresponded to the localization of PC. We identified $39.89 \pm 2.31 \mathrm{IHC}$-positive cells in PGC with PC and $36.48 \pm 2.46$ p53-positive cells in the field of view in PGC tissue without PC $(P>0.05)$ (Fig. $1 k)$. The Bax protein was identified as a cytoplasmic staining in tumor cells and atypical structures formed by them (Fig. 1/). $61.62 \pm 2.36$ Bax-positive cells had been found in 

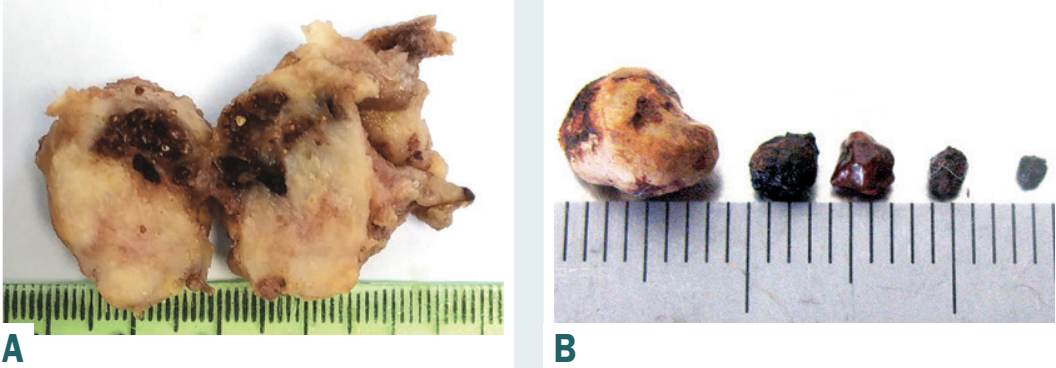

B
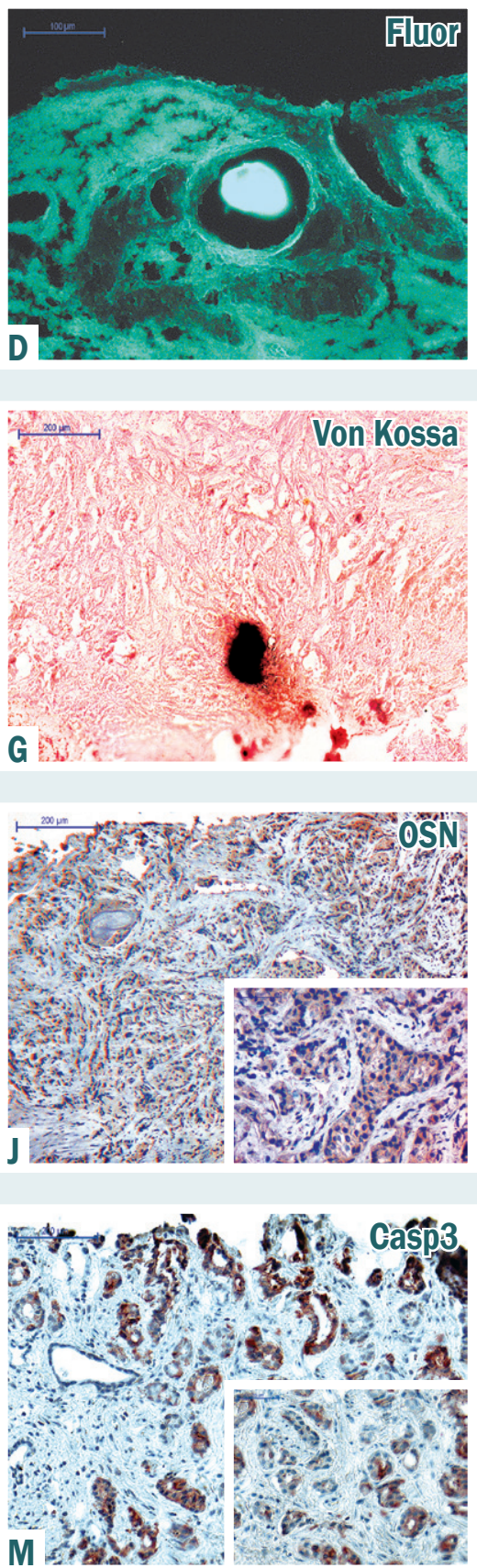
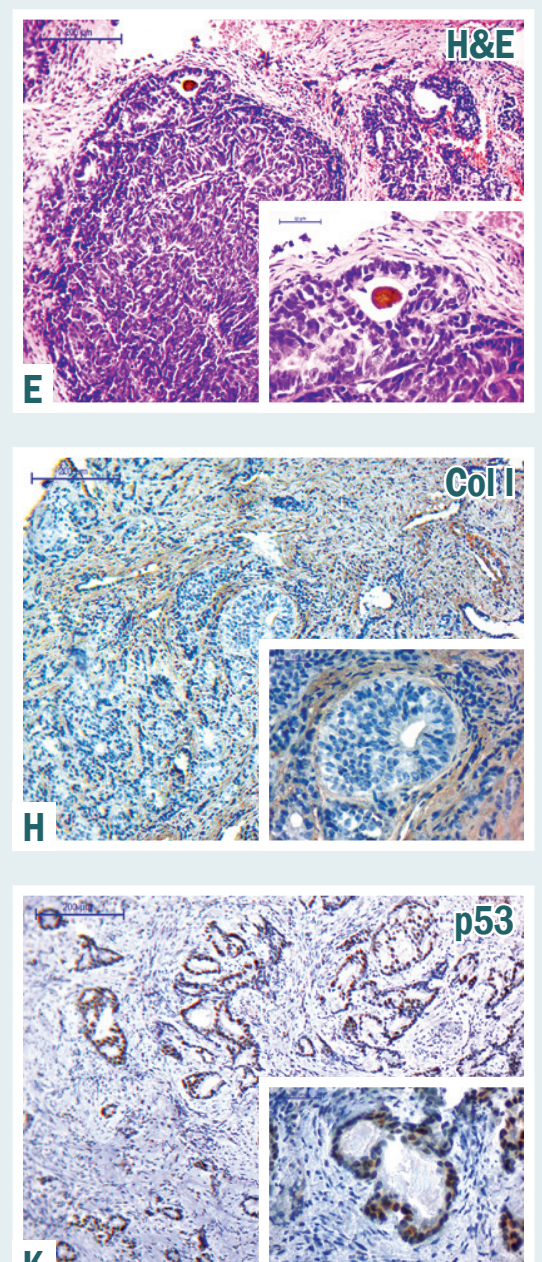

$K$ R.

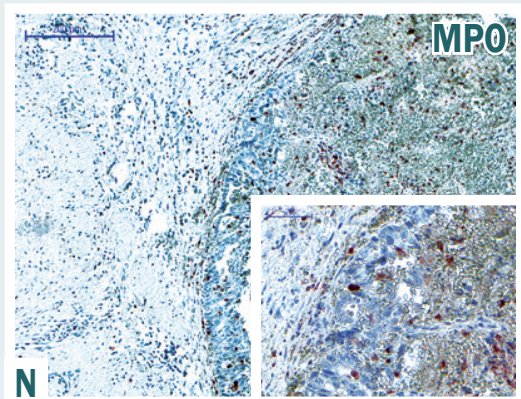

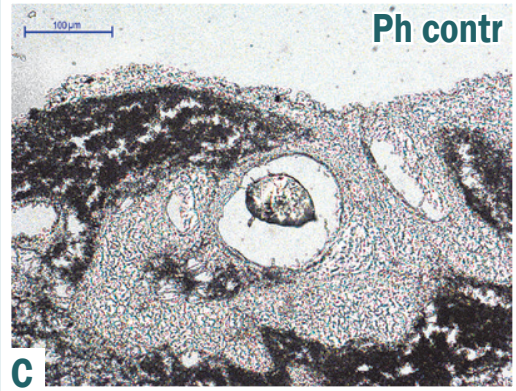
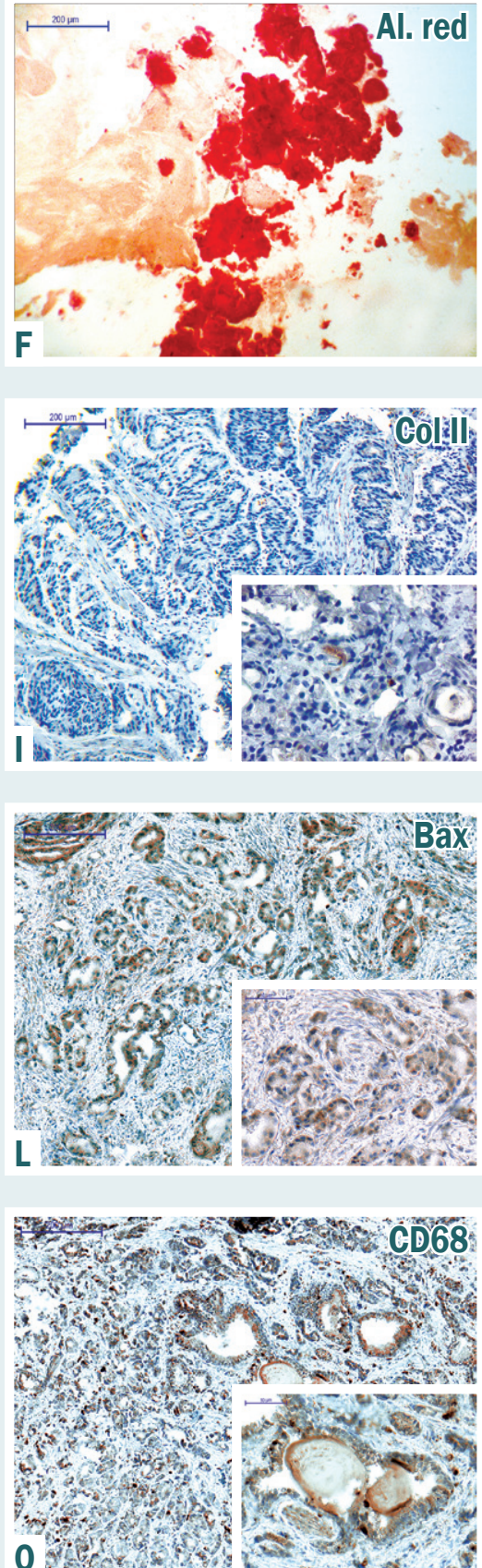

Fig. 1. Macroscopic, histological, histochemical examination and immunohistochemistry of PGC with PC.

A: PC in the prostate tissue, B: removed PC, C: PGC with PC in phase contrast, D: PC in fluorescence with excitation wave $495 \mathrm{~nm}$, E: hematoxylin-eosin staining

F: Alizarin red staining, G: Von Kossa staining, H: IHC with anti-Col I antibodies, I: IHC with anti-Col II antibodies, J: the expression of OSN, K: IHC detection of p53-positive cells, L: IHC with anti-Bax-antibodies, M: IHC with anti-Casp3-antibodies, N: IHC with anti-MPO-antibodies, 0: IHC detection of CD68. 

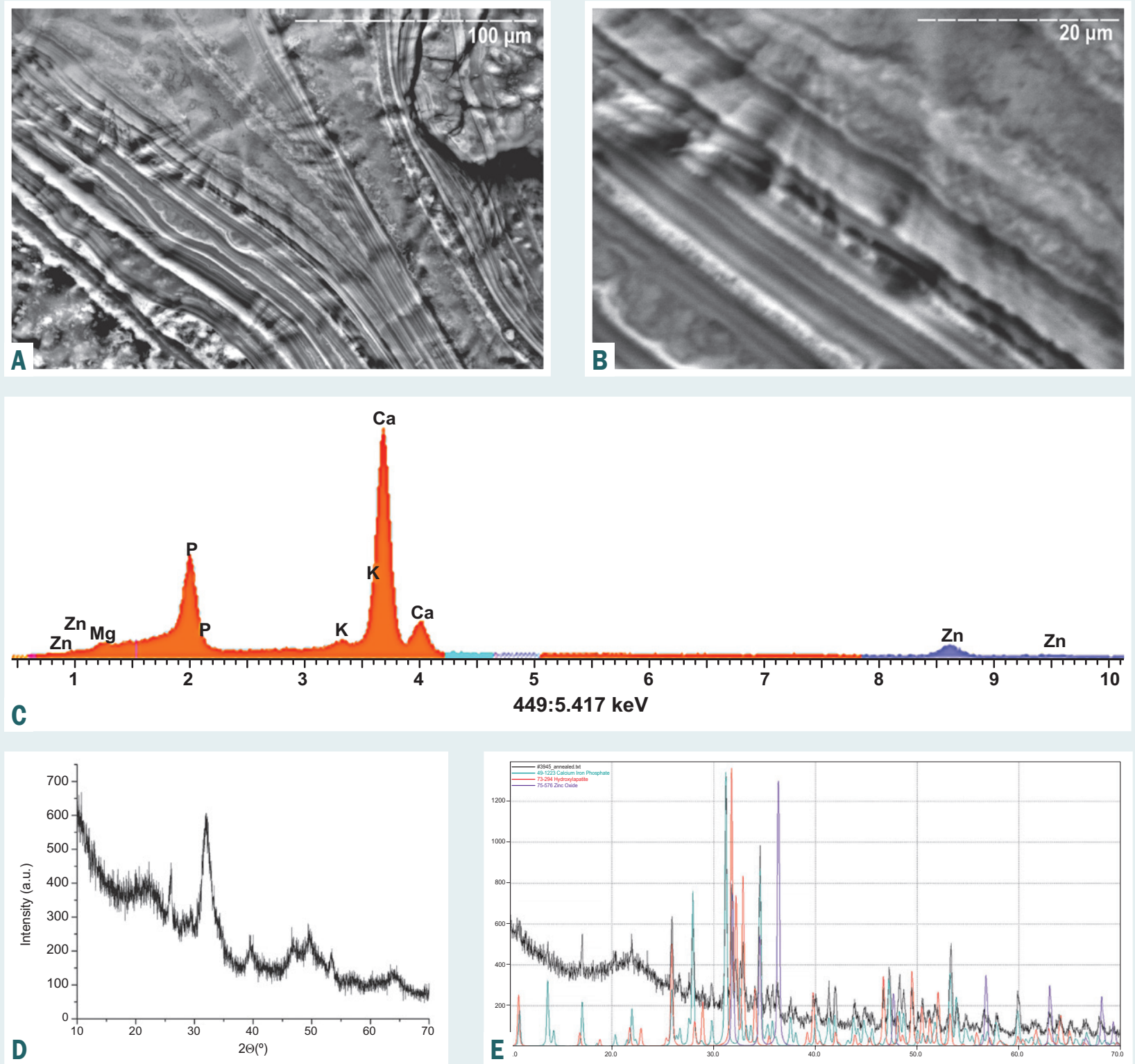

Fig. 2. Analysis of PCs: A-B: SEM of PC, C: SEM-EDS of PC surface, D: XRD after heat pretreatment at $200{ }^{\circ} \mathrm{C}$, E: XRD after heat pretreatment at $900{ }^{\circ} \mathrm{C}$ (purple - zink oxide, green - iron-containing calcium phosphate, red - hydroxyapatite). The magnification is indicated in the lower left corner of the image.

3

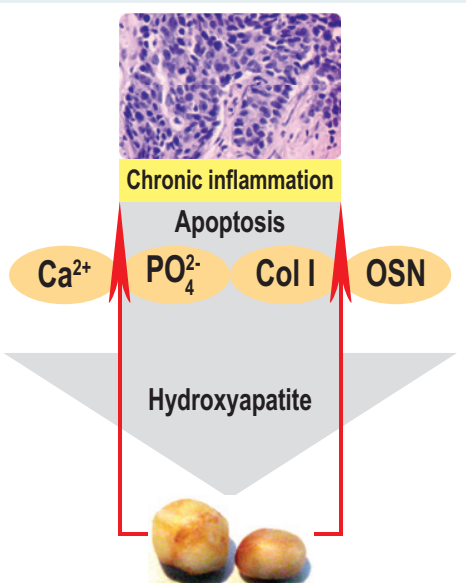

Fig. 3. Schematic representation of PC formation and its maintenance of chronic inflammation.

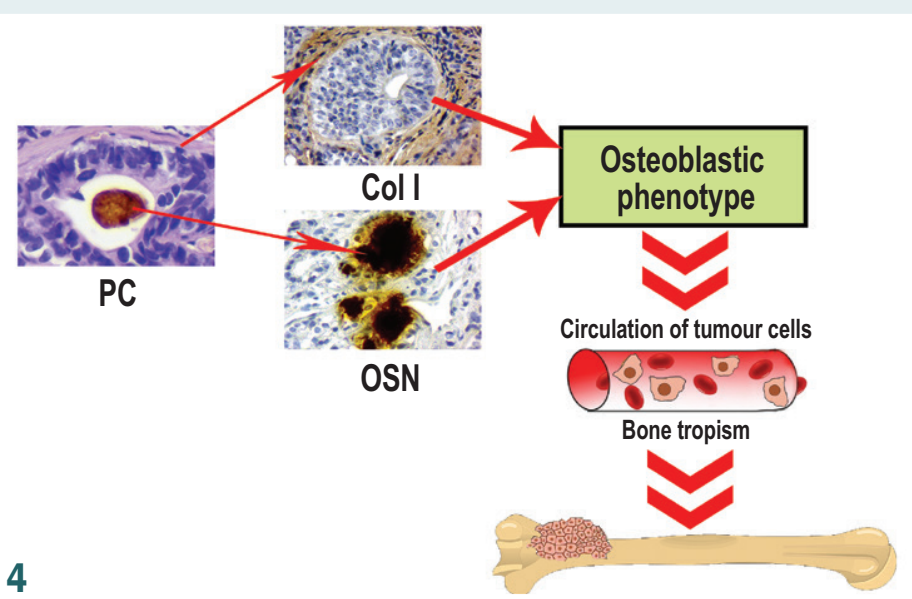

Fig. 4. The scheme of $P C$ impact on the osteoblastic phenotype development. 
$P G C$ with $P C$, whereas in the $P G C$ tissue without $P C$ this value was significantly lower $-44.62 \pm 2.94(P<0.001)$. The Casp3 protein had the cytoplasmic pattern of expression. The positive structures were represented predominantly by tumor cells and were located in small groups of atypical glandular complexes (Fig. $1 \mathrm{~m}$ ). There were $50.90 \pm 2.36$ Casp3-positive cells identified in the PGC tissue with PC. In the PGC tissue without PC $31.88 \pm 1.79(P<0.001)$ cells with Casp3 expression had been detected.

MPO-positive cells were detected in inflammatory infiltrates around PC, between tumor cells and their complexes as well as in tissue detritus (Fig. 1n). The number of cells with MPO-positive status in PGC tissue with PC was $31.50 \pm 1.71$. Only $13.89 \pm 1.26(P<0.001)$ MPO-positive cells were identified the prostate tumor tissue without PC.

CD68 had a cytoplasmic expression pattern. Positive cells were located as small groups of cells. They were identified both in the tumor tissue and in the stroma (Fig. 10). $137.48 \pm 3.39$ CD68-positive cells were detected in PGC with PC. PGC tissue without PC had the significantly lower number of CD68-positive cells $-92.145 \pm 4.120(P<0.001)$.

Determination of $P C$ mineral component. Scanning electron microscopy of PC showed their layered structure. In addition to concentric circles and plates, the structure of the PC was characterized by the presence of flat areas and areas with a finely porous surface (Fig. 2a). In some $\mathrm{PC}$ samples a wave-like deformation of mineral plates was detected which was perpendicular to the concentric lines (Fig. 2b). Surface analysis revealed the presence of small crystalline formations. These structures had polygonal or needle-like form. We also identified the presence of unstructured mineralized compound between the concentrically placed mineral plates of PC.

Mineral component of PC was also examined by energy-dispersion analysis. We revealed that the mineral component of PC predominantly consisted of calcium and phosphorus (Fig. 2C). The ratio of these elements corresponded to hydroxyapatite $(\mathrm{Ca} / \mathrm{P}=1.67)$. However, the presence of small amount of elements such as potassium, magnesium and zinc in majority of the cases indicated the high probability of isomorphous substitutions in the apatite structure and the possibility of coexistence of minor crystalline phases such as a magnesium-containing calcium phosphate ( $\beta$-tricalcium magnesium phosphate).

XRD revealed the presence of apatite with variation of crystallinity in all PC samples. The size of the crystals according to Scherrer (to the normal plane 002) varied from $14 \mathrm{~nm}$ to $30 \mathrm{~nm}$. These results show the similarity of $\mathrm{PC}$ crystallites to the physiological structure of bone tissue (Fig. 2d). PC heat pretreatment at $900{ }^{\circ} \mathrm{C}$ removes all organic compounds and splits biomineral to the main phases. We found the presence of zinc oxide and iron-containing calcium phosphate in the composition of the PC. These elements are essential for enzymes in PGC tissue (zinc) and hemoglobin (iron) (Fig. 2e).

\section{Discussion}

The development of PGC bone metastases can be explained by "seed and soil" theory. According to this theory cancer cells as seeds require appropriate microenvironment (soil) for survival and growth [12]. Numerous tumor cells are distributed randomly in all tissues. However, their successful growth and development is possible only with appropriate environment. So, bone tissue has the optimal environment characteristic for growth of PGC cells [2]. The analysis of presence of osteotropic proteins and PC formation in the PGC may indicate the primacy of calcification processes since prostatic stones are more common in benign hyperplasia. Previously, we found out that PC were detected in $27.60 \pm 3.48 \%$ of benign prostatic hyperplasia samples [13].

X-ray microanalysis revealed that all PC had the calcium phosphate origin in the form of apatite with high probability of inclusions of other chemical elements which is also characteristic of the biological apatite of the skeleton. Similar results were published by Sfanos et al. and Dessombz et al. [7,14]. The crystal structure of PC has a similarity to the mineral component of bone tissue, which manifests by the common crystalline and chemical features. Previously we have found the presence of carbonate substitutions in the structure of apatite, and also dimensional and morphological features of crystalline particles. The presence of carbonates in the structure of PC apatite (predominantly B-type, where the $\mathrm{CO}_{3}{ }^{2-}$ ions substitute $\mathrm{PO}_{4}{ }^{3-}$ groups) and the specificity of the shape of their crystals with typical sizes in a few dozen nanometers indicate the chemical and morphological affinity of PC ectopic apatite to physiological apatite of bone tissue. In both cases, the small crystal size causes a fairly high surface/volume ratio which is an evidence of large interaction area with the organic component or biological fluids, which should contain specific inhibitors or growth and regulators of crystals shape.

The mineralization processes require the presence of specific components of organic (collagenous and non-collagenous proteins, enzymes) and inorganic (calcium ions, phosphorus compounds) origin. We suggest that chronic inflammation is the source for components for PC development. It is confirmed by the fact that the samples of PGC with PC have shown an intense inflammatory infiltration compared to PGC without PC. It also has been confirmed by the presence of significant amount of MPO and CD68-positive cells in PGC tissue with $P C(P<0.001)$. On the background of intense inflammation, tissue of PGC with PC has high expression of proapoptotic Bax and Casp3 proteins $(P<0.001)$. The elevation of these markers expression (in comparison to $\mathrm{p} 53$ protein) indicates a preferential external mechanism of apoptosis activation in PGC with PC. This indicates a direct effect of PC on apoptosis in PGC tissue.

The combination of these processes (inflammation, apoptosis, the presence of cellular detritus and baring of connective tissue matrix) create a specific environment for the development of pathological biomineralization in PGC tissue. At the same time, the presence of PC supports chronic inflammation [15]. Thus, there is a "vicious circle", which is schematically summarized in Fig. 3. The presence of zinc oxide (a part of the metalloproteinases) and iron (as a result of chronic inflammation and hemorrhages) in a PC also confirms the chronic and undulating course of the biomineralization.

Our research indicates the presence of osteoblastic markers in tumor cells: a higher expression of Col I and OSN in PGC tissue with PC $(P<0.001)$. 
Acombination of PC and osteoblastic markers expression in PGC cells may indicate a close relationship between these phenomena. The presence of pathological biomineralization can create a modulating effect on cancer cells, contributing to the expression of some bone markers. In our opinion, this facilitates the recognition of bone tissue by circulating PGC cells as a niche for the development of metastases. This may facilitate the understanding of mechanisms of PGC bone metastases development. That is, a circulating tumor cell has an appropriate phenotype to search for a specific niche.

The results of our study are schematically presented in Fig. 4.

Thus, the assessment of osteoblastic markers expression in PGC can be used as criterion for evaluation of probability of bone metastases development. The presence of PC in PGC tissue can be an important prognostic information for clinicians.

\section{Conclusions}

1. The mineral part of all PC consists of calcium phosphates in the form of hydroxyapatite with signs of similarity to the mineral component of bone tissue.

2. The presence of $P C$ in PGC tissue is accompanied by the expression of inflammatory (CD68 and MPO) and apoptotic (Bax and Casp3) markers.

3. High expression of Bax and Casp3 indicates the external pathway of apoptosis activation in PGC with PC.

4. The presence of $P C$ promotes the expression of osteoblastic markers (OSN and Collagen I) in PGC tissue, which helps the tumor cells to recognize a favorable microenvironment. These phenomena can precisely determine the tropism of PGC metastases to bone tissue.

\section{Funding}

This research has been performed with the financial support of grants of the Ministry of Education and Science of Ukraine No. 0117U003937 "The development of method of reproductive system organs tumor diagnosis using cellular adhesion molecules of cancer-embryonic antigen" and No. 0118U003570 "The efficiency of "liquid biopsy" and tissue biopsy in the diagnosis and treatment of malignant tumors", Erasmus+ Project 2017-1-SE01KA107-034386 between Sumy State University and Umea University.

Conflicts of interest: authors have no conflict of interest to declare. Конфмікт інтересів: віАсутній.

Нааійшла Ао реАакції / Received: 15.04.2019

Після Аоопрацювання / Revised: 25.04.2019

Прийнято АО Аруку / Accepted: 13.05.2019

Information about authors:

Piddubnyi A. M., MD, PhD student, Department of Pathological Anatomy, Sumy State University, Ukraine.

Danylchenko S. M., PhD, Head of the Department of Biophysics and Mass-spectrometry № 20, Institute of Applied Physics, National Academy of Sciences of Ukraine, Sumy, Ukraine.

Romaniuk A. M., MD, PhD, DSc, Professor, Head

of the Department of Pathological Anatomy, Sumy State

University, Ukraine.

Moskalenko R. A., MD, PhD, DSc, Associate Professor

of the Department of Pathological Anatomy, Sumy State

University, Ukraine.
Відомості про авторів:

Підаубний А. М., аспірант каф. патологічної анатомії, Сумський Аержавний університет, Україна.

Аанильченко С. М., канА. фіз.-мат. наук, зав. віАділу біофізики та мас-спектрометрії № 20, Інститут прикладної фізики Національної академії наук України, м. Суми, Україна. Романюк А. М., А-р меА. наук, професор, зав. каф. патологічної анатомії, Сумський Аержавний університет, Україна. Москаленко Р. А., А-р меА. наук, Аоцент каф. патологічної анатомії, Сумський державний університет, Україна.

\section{Сведения об авторах:}

ПоААубный А. М., аспирант каф. патологической анатомии, Сумский государственный университет, Украина. Аанильченко С. Н., канА. физ.-мат. наук, зав. отАела биофизики и масс-спектрометрии № 20, Институт приклаАной физики Национальной академии наук Украины, г. Сумы, Украина. Романюк А. Н., А-р меА. наук, профессор, зав. каф. патологической анатомии, Сумский государственный университет, Украина.

Москаленко Р. А., А-р меА. наук, Аоцент каф. патологической анатомии, Сумский государственный университет, Украина.

\section{References}

[1] Chen, S. L., Wang, S. C., Ho, C. J., Kao, Y. L., Hsieh, T. Y., Chen, W. J. et al. (2017). Prostate Cancer Mortality-To Incidence Ratios Are Associated with Cancer Care Disparities in 35 Countries. Sci. Rep, 7, 40003. doi: $10.1038 /$ srep 40003

[2] Hensel, J., \& Thalmann, G. N. (2016). Biology of Bone Metastases in Prostate Cancer. Urology, 92, 6-13. doi: 10.1016/j.urology.2015.12.039

[3] Bernstein, A. N., Shoag, J. E., Golan, R., Halpern, J. A., Schaeffer, E. M. Hsu, W. C. et al. (2018). Contemporary Incidence and Outcomes of Prostate Cancer Lymph Node Metastases, J. Urol, 199(6), 1510-1517. doi: 10.1016/j. juro.2017.12.048

[4] Coleman, R. E. (2006). Clinical features of metastatic bone disease and risk of skeletal morbidity. Clin. Cancer Res, $12(20$ Pt 2), 6243s-6249s. doi: 10.1158/1078-0432.CCR-06-0931

[5] Sfanos, K. S., Isaacs, W. B., \& De Marzo, A. M. (2013). Infections and inflammation in prostate cancer. Am J Clin Exp Urol, 1(1), 3-11.

[6] Dell'Atti, L., Galosi, A. B., \& Ippolito, C. (2016). Prostatic calculi detected in peripheral zone of the gland during a transrectal ultrasound biopsy can be significant predictors of prostate cancer. Arch. Ital. Urol. Androl, 88(4), 304-307. doi: 10.4081/aiua.2016.4.304

[7] Sfanos, K. S., Wilson, B. A., De Marzo, A. M., \& Isaacs, W. B. (2009). Acute inflammatory proteins constitute the organic matrix of prostatic corpora amylacea and calculi in men with prostate cancer. Proc. Natl. Acad. Sci. U.S.A., 106(9), 3443-3448. doi: 10.1073/pnas.0810473106

[8] Hagberg Thulin, M., Jennbacken, K., Damber, J. E., \& Welén, K. (2014). Osteoblasts stimulate the osteogenic and metastatic progression of castration-resistant prostate cancer in a novel model for in vitro and in vivo studies. Clin. Exp. Metastasis, 31(3), 269-283. doi: 10.1007/s10585-013-9626-1

[9] Kawai M., \& Rosen C. J. (2012). The Insulin-Like Growth Factor System in Bone. Basic and Clinical Implications. Endocrinol. Metab. Clin. North Am 41(2), 323-333. doi: 10.1016/j.ecl.2012.04.013

[10] Park, S. H., Eber, M. R., Widner, D. B., \& Shiozawa, Y. (2018). Role of the Bone Microenvironment in the Development of Painful Complications of Skeletal Metastases. Cancers (Basel), 10(5). doi: 10.3390/ cancers10050141

[11] Rucci, N., \& Teti, A. (2010). Osteomimicry: how tumor cells try to deceive the bone. Frontiers in Bioscience, 2(3), 907-915. doi: 10.2741/S110

[12] Gdowski, A. S., Ranjan, A., \& Vishwanatha, J. K. (2017). Current concepts in bone metastasis, contemporary therapeutic strategies and ongoing clinical trials. J. Exp. Clin. Cancer Res, 36(1), 108. doi: 10.1186/s13046-017-0578-1

[13] Moskalenko, R., Romanyuk, A., Danilchenko, S., Stanislavov, O., Piddubniy, A., Zakorko, I. -M., \& Tkach G. (2013). Morphogenetic aspects of biomineralization on the background of benign prostatic hyperplasia. Georgian Medical News, 214, 54-61.

[14] Dessombz, A., Méria, P., Bazin, D., \& Daudon, M. (2012). Prostatic Stones: Evidence of a Specific Chemistry Related to Infection and Presence of Bacterial Imprints. PLOS One, 7(12), e51691. doi: 10.1371/journal. pone. 0051691

[15] Hyun, J. S. (2018). Clinical Significance of Prostatic Calculi: A Review. The World Journal of Men's Health, 36(1), 15-21. doi: 10.5534/wjmh.17018 